\title{
Alternative Fuel Vehicles
}

Adding energy-efficient alternative fuel vehicles to Federal fleets enhances energy security, reduces fuel imports, and benefits the environment

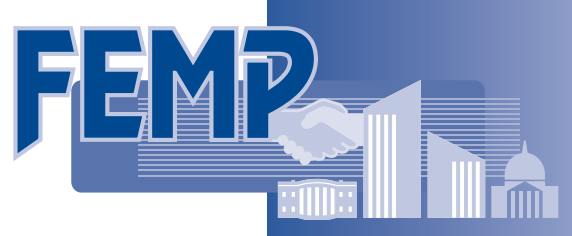

\section{Executive Summary}

Relying more on domestic fuels and less on imported petroleum will enhance the nation's energy security, help to curb air emissions, and serve as a hedge against fluctuating fuel prices. To reduce petroleum imports, the Energy Policy Act of 1992 (EPAct) has called for reductions in the consumption of gasoline and diesel fuel in automobiles, among other requirements. Currently, more than 160 billion gallons of gasoline and diesel fuel are consumed each year in more than 200 million vehicles on U.S. roads. And nearly 13 million of those vehicles are operated by fleet owners. Therefore, EPAct focuses on the potential for reducing petroleum use in U.S. vehicle fleets, particularly the numerous fleets owned and operated by the Federal government.

EPAct stipulates that $75 \%$ of the new, light-duty vehicles purchased by Federal fleets each year must be alternative fuel vehicles (AFVs) — cars and trucks that operate on fuels other than gasoline and diesel. Executive Order 13149, signed in 2000, goes on to require Federal fleets to use alternative fuels to achieve a $20 \%$ reduction in on-road petroleum consumption by 2005. Designated alternative fuels include methanol, ethanol, and

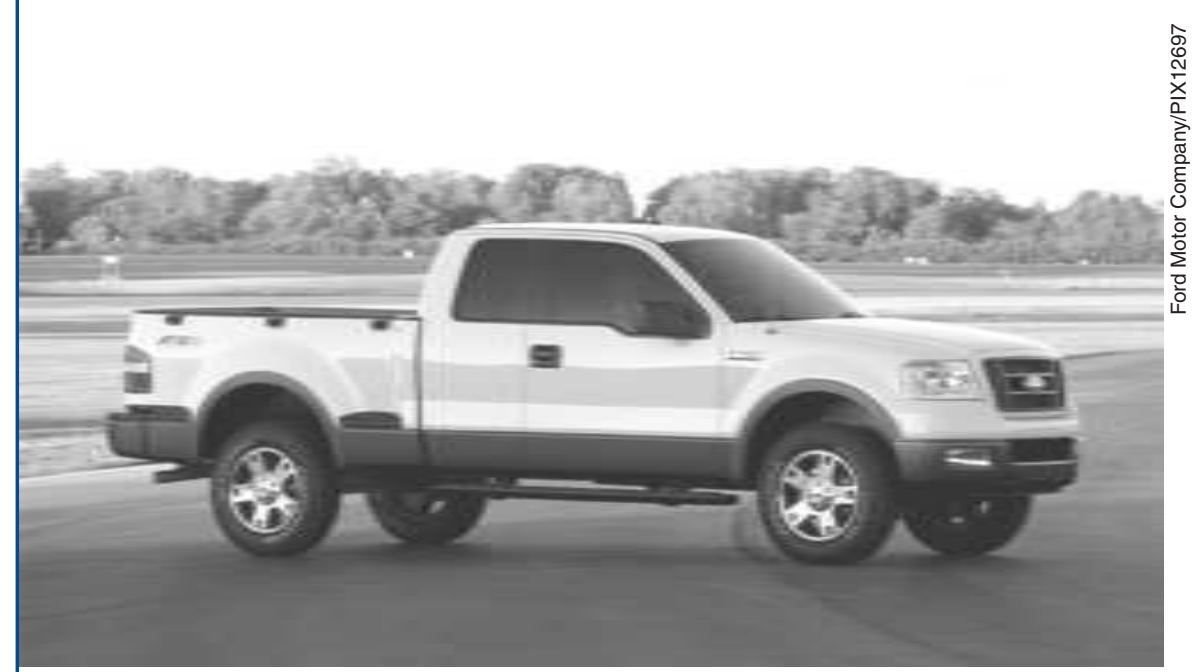

This 2004 flexible-fuel Ford F150 pickup has been redesigned to have a more spacious interior; it is a popular model for fleets as well as individual drivers. other alcohol fuels; biodiesel; natural gas and liquid fuels produced domestically from natural gas; hydrogen; electricity; and propane.

Several different kinds of AFVs can be purchased directly from major manufacturers, and they are available in a wide range of models and styles. But alternative fuels are still not widely available, and this is the biggest challenge for Federal fleets that want to acquire AFVs. On-site stations can be adapted for fleets that are refueled centrally. But when fleet vehicles need to be driven a great distance from the central station, it can be difficult to locate stations with alternative fuels. Therefore, one of the best options for today's fleets is to use a combination of traditionally fueled vehicles and AFVs.

This Federal Technology Alert, one of a series on new technologies prepared by the Federal Energy Management Program (FEMP) in the Department of Energy (DOE), describes the Federal government's plans and progress in meeting the goals for AFVs stated in EPAct and the Executive Order. It describes the types of alternative fuels and AFVs currently available; lists actual and potential uses in Federal fleets; makes some general recommendations, which vary according to a facility's needs and capabilities; and presents some field experiences to date.

\section{Energy-Saving Mechanism}

Alternative fuel vehicles save energy in several ways. For example, using AFVs reduces the consumption of traditional transportation fuels, and this helps to conserve domestic oil resources. Every gallon of alternative fuel we use
Leading by example, saving energy and taxpayers dollars in federal facilities

\section{Federal} Technology Alert

\section{A New Technology \\ Demonstration \\ Publication}

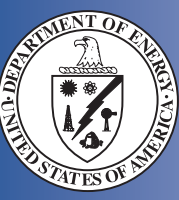

U.S. Department of Energy Energy Efficiency and Renewable Energy

Bringing you a prosperous future where energy is clean, abundant, reliable, and affordable 


\section{F E D ERAL EN ERG Y}

displaces an equal amount of petroleum fuel. And each Federal lightduty AFV can displace an average of about 600 gallons of gasoline per year. If just $20 \%$ of the Federal fleet, which includes about 478,000 lightduty vehicles, were converted to domestically produced alternative and renewable fuels, approximately 54 million gallons of gasoline and diesel fuel could be saved each year.

\section{Potential Applications}

Large Federal fleets that are refueled centrally are probably the strongest candidates for AFVs, for several reasons. For example, large fleet operators usually need some new vehicles every year, and this provides many new opportunities to increase the use of AFVs. And large fleets can usually purchase AFVs in greater volume than smaller fleets can.

In addition, large fleet operators often have on-site refueling stations that can readily be converted to provide alternative fuels, which makes it easier to use AFVs. Building a new alternative fueling station can be costly. But converting an existing station to ethanol, for example, can be relatively inexpensive, because the tanks and pumps needed are already on the site.

Large fleets that use local commercial refueling stations rather than on-site stations can also be good candidates for AFVs. These fleets are usually reliable customers that make extensive use of a commercial station. So, they can be in a good position to negotiate new refueling capabilities with the station's owner.

Although large fleets have the advantage, many smaller fleets can be good candidates for AFVs, as well. Factors such as the agency's mission, the availability of funds and fuels, and incentives can help smaller fleets to acquire these vehicles.
Incorporating AFVs into fleets of any size requires careful evaluation and planning. Fleet operators will want to evaluate their needs and determine the costs and capabilities of different vehicles as well as the availability of reliable fuel supplies. For example, one agency might choose ethanol vehicles because they tend to have lower incremental costs than other AFVs and can be refueled on the agency's sites. Another agency might decide to buy natural gas vehicles for its large fleet of pickup trucks, after finding that natural gas trucks are widely available and refueling equipment can be connected directly to the agency's existing gas lines. So, agencies must consider several different factors when purchasing AFVs for Federal applications.

\section{Field Experiences}

Many Federal fleets already include AFVs; each year, more than 7,500 new ones are acquired. To facilitate these acquisitions, the government has established some innovative ways to budget for AFVs. The most prominent is the GSA surcharge program, in which a Federal agency agrees to a fixed monthly surcharge on every GSA vehicle it leases. The surcharge money then helps to pay for the new AFVs that the agency purchases the following year. All the agency's fleets thus contribute to its compliance with EPAct and the Executive Order, whether or not the fleet includes AFVs. The U.S. Army and DOE both participate in this program.

Both field experiences and laboratory tests show that AFVs match their conventionally fueled counterparts in performance as well as operating costs. And reliable fuel supplies, as well as the number of refueling stations, are on the increase. Fleets can now use DOE's alternative fuel refueling locator (www.afdc.doe.gov/ refueling.html) to determine the closest alternative fueling stations and to map trips.

\section{Implementation Barriers}

The primary barriers to greater Federal use of AFVs are the lack of a widespread refueling infrastructure and typically higher vehicle costs. These barriers are not easy to overcome. For example, potential buyers might hesitate to purchase AFVs in large volume until commercial refueling stations are readily available. At the same time, station owners might hesitate to invest in the refueling infrastructure until there are enough AFVs to make it a good investment.

Volume purchases could be one of the most effective ways to help bring down the cost of many types of AFVs. The added cost of an AFV currently ranges from very little for certain vehicles that run on ethanol to about $\$ 1,700-\$ 7,800$ for those that run on compressed natural gas.

To help break down barriers like these, the Federal government provides incentives to fleets acquiring AFVs. And new legislation is proposed frequently to stimulate the AFV market.

\section{Conclusion}

There is enormous potential in the Federal government to make greater use of alternative fuels. Therefore, among other measures, the Energy Policy Act of 1992 calls for Federal fleets to adopt a leadership role in acquiring motor vehicles that run on these fuels. However, it takes time and careful planning to evaluate the needs of an agency or a facility and determine the best vehicles for a particular budget, application, and location. But making the effort can yield great returns. Using AFVs not only helps agencies meet Federal requirements, it also contributes to the nation's energy security by replacing some of our imported petroleum with domestic fuels. 


\section{Federal Technology Alert: Alternative Fuel Vehicles}

\section{Adding energy-efficient alternative fuel vehicles to Federal fleets enhances energy security, reduces fuel imports, and benefits the environment}

\section{Abstract}

Alternative fuel vehicles (AFVs) — cars and trucks that operate on fuels other than gasoline and diesel-are beneficial to the Federal government, and the nation as a whole, in several ways. For example, they enhance our energy security by reducing the need for imported fuels, and they improve air quality by reducing the emissions associated with many vehicles that use traditional transportation fuels.

The Energy Policy Act of 1992 (EPAct) was established in large part to reduce the nation's dependence on imported petroleum. One objective of EPAct is to encourage the use of AFVs in the Federal government's vehicle fleets. Currently, $75 \%$ of annual light-duty vehicle acquisitions in Federal fleets are required to be AFVs. In addition, Executive Order 13149, signed in April 2000, states that alternative fuels can be a major contributor to the goal of cutting the Federal fleet's use of petroleum by $20 \%$ by 2005 . Vehicles that run on alternative fuels also help the nation conserve domestic fossil fuel resources.

Because the Federal government has such a large number of fleet vehicles, it is uniquely positioned to make greater use of AFVs. The government has

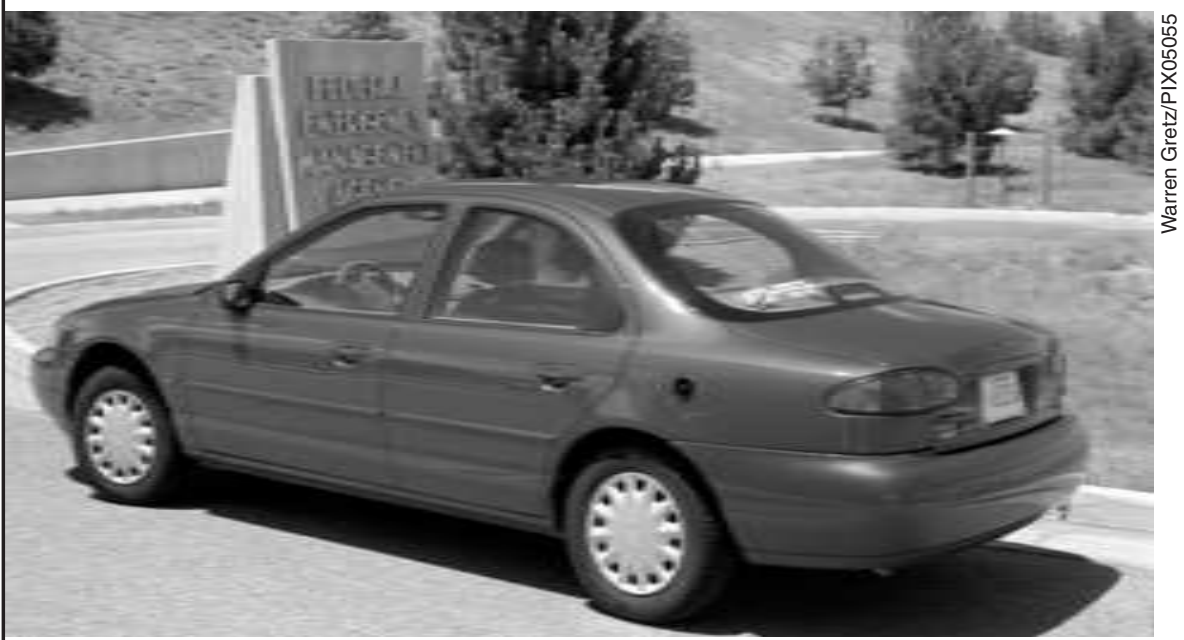

The bi-fuel Ford Contour, which runs on compressed natural gas (CNG) as well as gasoline, was selected to be part of the General Services Administration's Colorado fleets in 1997. therefore been encouraged to take a leading role in advancing alternative fuel technologies. Alternative fuels are advantageous not just because of their role in reducing the need for imported petroleum but also because of their "clean fuel" attributes. Vehicles running on alternative fuels typically produce fewer tailpipe emissions of certain air pollutants.

In addition, fleet vehicles of any kind typically accumulate higher annual mileages than private vehicles do, so they must be replaced more often. Therefore, adding AFVs to Federal fleets can shorten the amount of time it takes to improve air quality and achieve U.S. goals for energy independence.

Well over 400,000 AFVs are currently in use in the United States, and more than 30,000 AFVs are operating in the Federal fleet. Operator surveys show that these vehicles have been well received. Alternative fuel vehicle technology has improved significantly in just a few years' time. And nearly every major vehicle manufacturer offers a variety of models that run on alternative fuels.

This Federal Technology Alert was prepared to inform Federal fleet operators and others about the tremendous potential and benefits of AFVs. It provides information about alternative fuels as well as about the vehicles, and it includes data on associated costs, fuel availability, performance attributes, and emissions. 


\section{Contents}

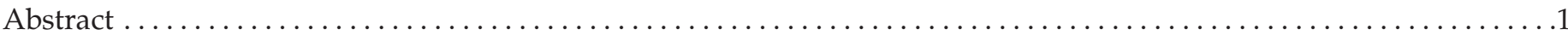

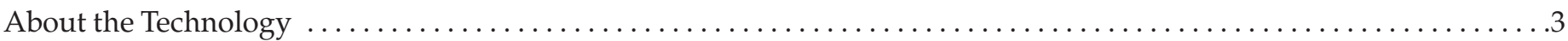

Application Domain

Energy-Saving Mechanism

Other Benefits

Variations

Installation

Federal-Sector Potential

Estimated Savings and Market Potential

Laboratory Perspective

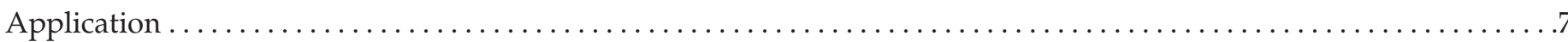

Application Screening

Where to Apply

What to Avoid

Equipment Integration

Maintenance Impact

Equipment Warranties

Codes and Standards

Costs

Utility Incentives and Support

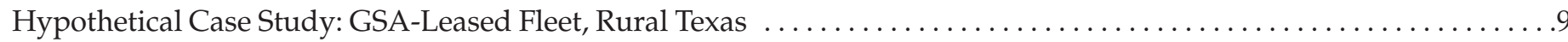

Facility Description

Existing Technology Description

New Technology Equipment Selection

Savings Potential

Implementation and Post-Implementation Experience

The Technology in Perspective .11

The Technology's Development

Technology Outlook

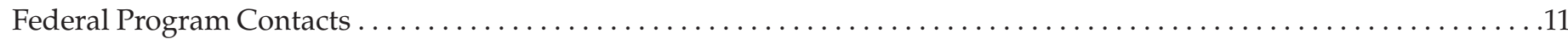

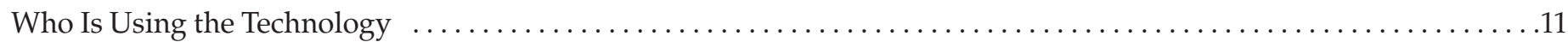

Federal Sites

Non-Federal Sites

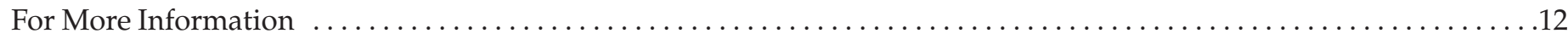

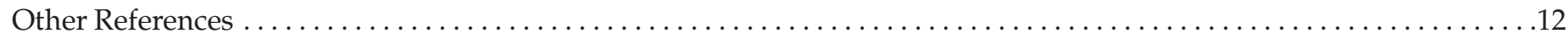

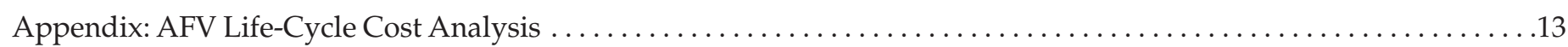




\section{About the Technology}

Alternative fuel vehicles (or AFVs) are cars and trucks that can operate on a fuel other than gasoline or diesel fuel. These vehicles are available from nearly all of the major U.S. automobile manufacturers in a wide range of vehicle models and classes.

Several different configurations of vehicles are considered to be alternative fuel vehicles. There are two broad categories: dedicated AFVs and dualfuel AFVs.

\section{- Dedicated AFVs: Dedicated vehicles} operate exclusively on an alternative fuel. The most common ones are compressed natural gas and propane.

- Dual-fuel AFVs: Dual-fuel vehicles operate on two different types of fuel, either simultaneously or independently. The two most common types are bi-fuel and flexible-fuel vehicles.

- Bi-fuel vehicles: These dual-fuel vehicles have one fuel tank and fuel system for an alternative fuel and another fuel tank and fuel system for gasoline or diesel; the vehicle can operate on one of the two fuels at a time. These most commonly operate on compressed natural gas and gasoline or diesel.

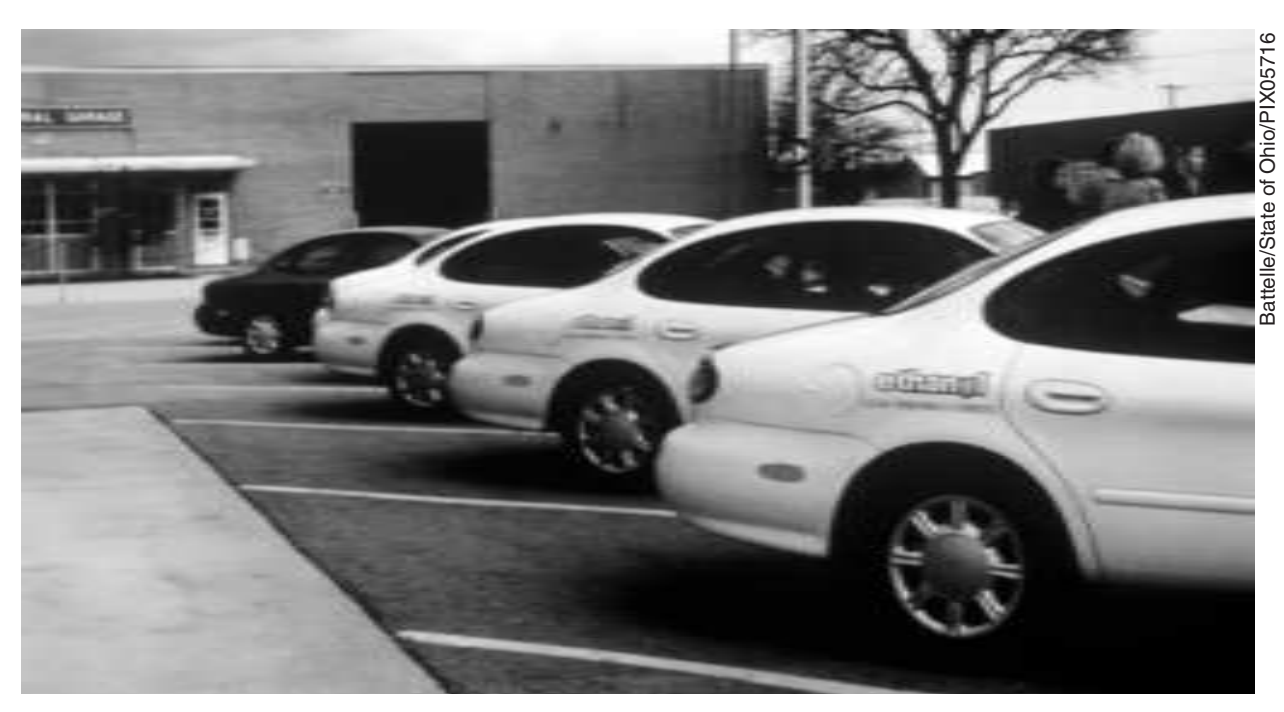

In 1996, Ford Taurus E85 flexible-fuel vehicles were part of the State of Ohio's fleets.

- Flexible-fuel vehicles: A flexible-fuel vehicle (or FFV) has one fuel tank and fuel system that can accept either of two kinds of liquid fuels, such as blends of gasoline and ethanol, which are the most common fuels in use in flexible-fuel vehicles today. In the past, methanol was also used.

In addition to AFVs, some traditional diesel vehicles can operate on renewable fuels. These vehicles are not considered to be AFVs, but they can help an agency minimize the amount of petroleum used in its fleets and assist the agency in complying with regulations governing its fleets.

The alternative fuels you can use in your agency's AFVs come in a variety of forms, but all share the common characteristic of being derived substantially from nonpetroleum sources. The major alternative fuels used widely today include these:

- Ethanol: An alcohol fuel currently produced from grain, agricultural waste, and biomass, ethanol is a fuel oxygenate or additive in several areas of the country. Ethanol is generally used in blends of E85, which is $85 \%$ ethanol and $15 \%$ gasoline. Refueling stations dispense ethanol in much the same way that they dispense gasoline, using underground or above-ground tanks and a liquid fuel dispensing pump.

- Natural gas: This is primarily a methane fuel that occurs naturally in the Earth. It is used in vehicles either as compressed natural gas (CNG) or liquefied natural gas (LNG); LNG is less common. CNG can be dispensed in two ways: slowfill or fast-fill. In slow-fill refueling, vehicles are attached to a rather small, inexpensive unit that fills the vehicle slowly over a period of several hours. Fast-fill stations are more complex and fill a vehicle in a few minutes. Because CNG is a gaseous fuel, high-pressure compressors are required at refueling stations.

- Electricity: This can be taken from the power grid and stored in batteries on board the vehicle. Charging stations used to recharge the batteries of electric vehicles can usually be installed fairly inexpensively, and they can charge a vehicle over a period of hours, depending on the vehicle and battery type.

- Propane: This liquefied fuel is a byproduct of natural gas processing or petroleum refining.

- Biodiesel: Produced from vegetable oil or animal fat, biodiesel is typically a blend of $20 \%$ biodiesel with $80 \%$ conventional diesel fuel. Biodiesel can be used in traditional diesel engines and vehicles. Biodiesel is dispensed in much the same way that gasoline, diesel, and ethanol fuels are dispensed.

Some other alternative fuels are currently not as commercially available as those described above:

- Methanol: Methanol is an alcohol fuel produced from natural gas, coal, or biomass.

- P-series fuels: These are special blends of ethanol, methyltetrahydrofuran (MTHF), natural gas liquids, and butane. 


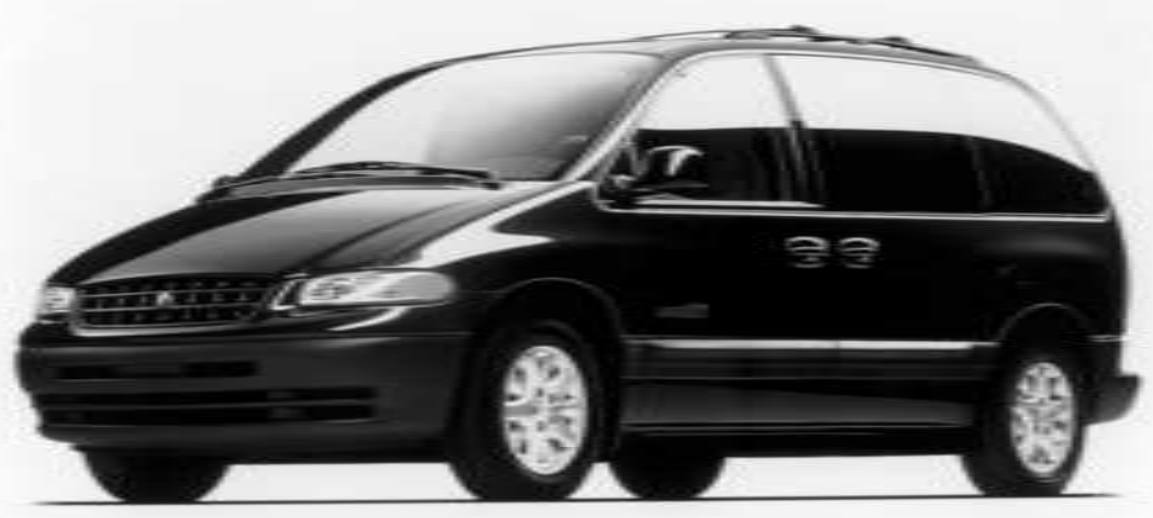

About 150,000 E85 Chrysler minivans like this one were available to U.S. fleets in 1998.

- Liquids from natural gas: High-quality, low-sulfur diesel fuel can be produced from natural gas using a series of steps known collectively as the Fischer-Tropsch process. Fischer-Tropsch diesel can be used in traditional diesel engines.

Each of these alternative fuels has unique characteristics, and each has specific advantages and disadvantages in comparison to traditional fuels such as gasoline and diesel. It is important to consider these differences when assessing each fuel's capabilities and availability. The cost analysis in the Appendix provides more details on the characteristics of these alternative fuels.

\section{Application Domain}

The Federal government estimates that it will have approximately 34,000 light-duty alternative fuel vehicles in service by the end of 2001, about $50 \%$ more than were in service in 1995.

Despite that rapid growth, the number of AFVs in use represents only a small fraction of the 575,000 light-duty and heavy-duty vehicles that make up the total Federal fleet. So, there is tremendous potential to expand their use.

Most Federal agency fleets are required to add alternative fuel vehicles to their inventory; however, even fleets not required to comply with legislative mandates should consider adopting this technology because of its potential to displace imported petroleum in the transportation sector.

Although AFVs are becoming much more widely available, the refueling infrastructure needed to support each alternative fuel is still not established in all areas. The best locations for alternative fuels and AFVs are major metropolitan areas where the fuels are commercially available. However, these fuels are also suitable for fleets large enough to support their own refueling stations, in almost any area.

\section{Energy-Saving Mechanism}

Alternative fuel vehicles offer certain energy security benefits in comparison to conventional vehicles. Each gallon of alternative fuel used displaces a gallon of petroleum fuel. Each Federal light-duty AFV that uses alternative fuels displaces an average of 600 gallons of gasoline per year. When we consider the potential across the entire Federal fleet, which has approximately 478,000 light-duty vehicles, the potential savings, if just $20 \%$ of the fleet converted to domestically produced alternative and renewable fuels, would be approximately 54 million gallons of gasoline and diesel fuel each year.

Because of this enormous potential, in 1992 Congress passed the Energy Policy Act (EPAct, P.L. 102-486); among other measures, EPAct promotes the use of alternative fuels in the transportation sector. Federal agencies are required under EPAct to begin acquiring AFVs in their fleets of 20 or more vehicles at the rate of $75 \%$ of covered light-duty vehicle acquisitions each year. Covered vehicles include all light-, medium-, and

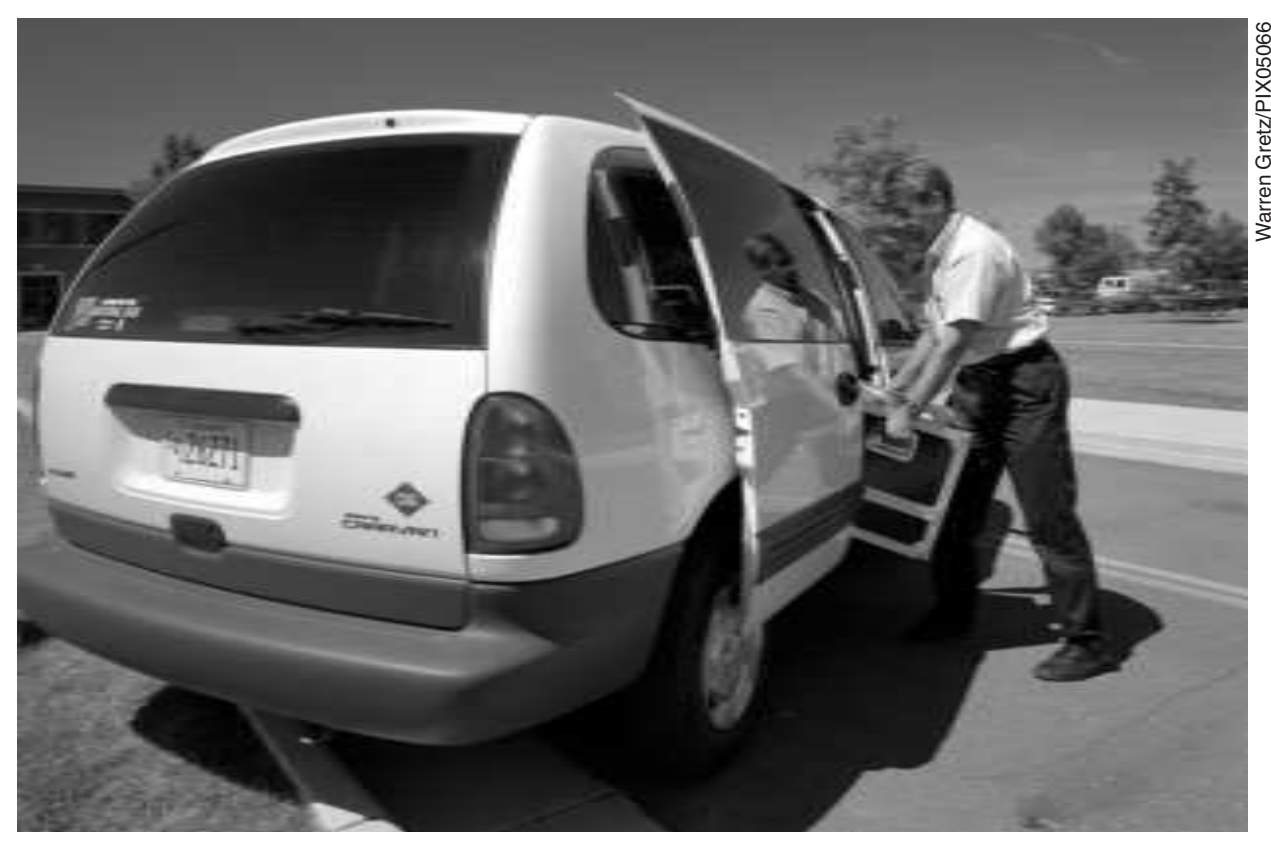

The GSA fleet at the Denver Federal Center in Colorado has included CNG-powered Dodge Caravans like this one. 


\section{F E D E R A L}

E N E R G Y heavy-duty fleet vehicles that are centrally fueled or capable of being centrally fueled. Under EPAct, exempt vehicles include law enforcement, emergency, and military tactical vehicles as well as fleet vehicles weighing more than 8,500 lb. (gross vehicle weight rating).

Executive Orders also promote the use of alternative fuels and vehicles in the Federal fleet. The most recent one, Executive Order 13149, was signed in April 2000. It supports EPAct acquisition requirements and also requires Federal agencies to reduce their petroleum use in fleet vehicles by $20 \%$ by the end of FY 2005. Covered and exempt vehicles are similar to those named in EPAct.

Alternative fuels are an important part of the road map to successfully meeting these goals. In addition, Federal agencies are asked to use more energyefficient vehicles (those with higher fuel economy) of all kinds, and to improve their fleet management techniques to minimize vehicle miles traveled.

\section{Other Benefits}

Alternative fuel vehicles have a significant environmental benefit in terms of reducing air pollution. In general, two types of pollution are related to automobiles: ground-level air pollution and greenhouse-gas (GHG) emissions in the atmosphere.

Ground-level air pollution is the type that causes smog. It is emitted from tailpipes as a by-product of the combustion process. This type of pollution contains several smog-forming gases as well as particulates, which can present respiratory health risks. Clean-burning alternative fuels such as CNG can greatly reduce the amount of ground-level air pollution emitted from vehicle tailpipes.

The second type of pollution, associated with the so-called greenhouse gases, is emitted from the burning of petroleum products. This pollution does not con- tribute directly to ground-level pollution problems but rather to problems in the atmosphere. All the alternative fuels greatly reduce the amount of GHG pollution in comparison to the use of petroleum. For example, using CNG instead of gasoline in today's vehicles results in a $6.7 \%$ decrease in GHG, and using E85 results in a 25.8\% decrease (see also Michael Q. Wang, Near Term Technology for MY 2000 Vehicles, Greet 1.5a Model Results, Argonne National Laboratory, Argonne, IL, April 2000).

\section{Variations}

Because several different kinds of alternative fuels are available, it can be difficult to select the type that will work best in your agency's particular fleet. Not all fuels perform the same way under all conditions. However, perhaps the first thing to determine is whether refueling stations that supply alternative fuels are available in your area. If so, it is a good idea to try to use those stations as much as possible. For instance, if there are several CNG stations nearby, you might want to consider selecting CNG as one of your AFV options.

If there are no appropriate refueling stations nearby, however, you might want to select the fuel that fits best with your geographic situation (including average temperatures and

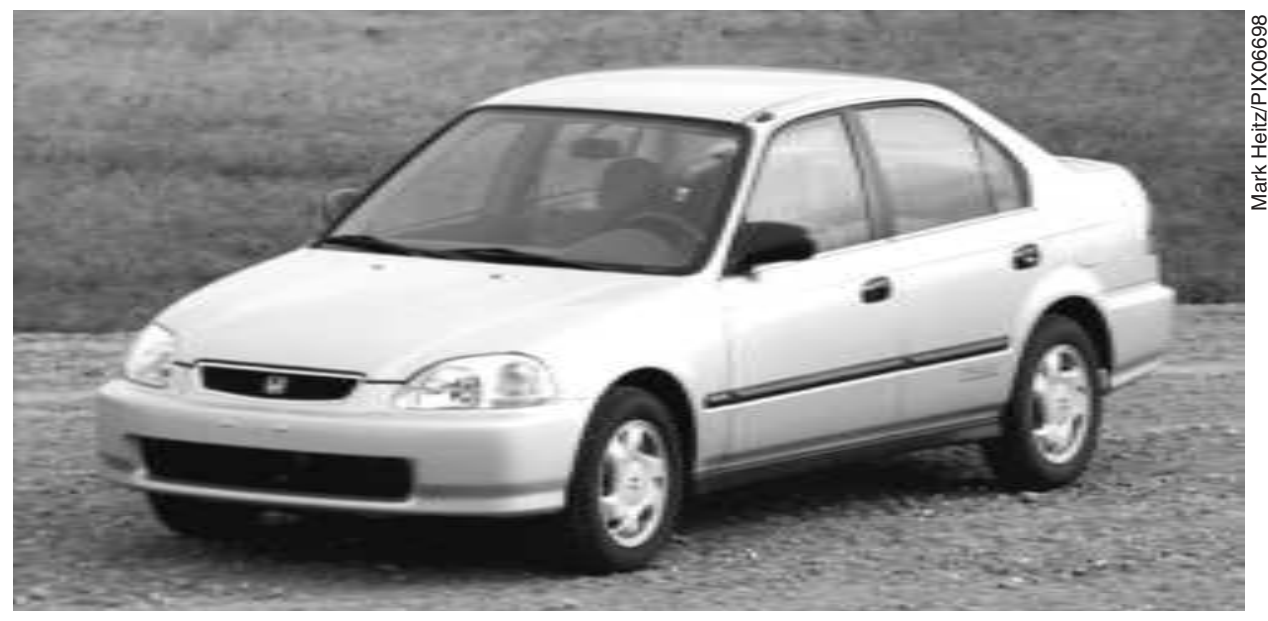

The 1998 Honda Civic GX, a dedicated CNG vehicle, is one of several types tested at the DOE National Renewable Energy Laboratory. altitude) and with the goals of your fleet and then make arrangements for refueling. For example, if one of the goals in your area is to reduce smog, you might want to select CNG, which has major local air pollution benefits in comparison to other fuels. However, if you are trying to minimize your fleet's GHG emissions, you might want to consider ethanol or biodiesel fuels that are produced completely from renewable biomass, because they emit very few GHGs.

\section{Installation}

Converting traditional fleet vehicles to $\mathrm{AFVs}$ requires both the acquisition of vehicles and the availability of a refueling infrastructure. Sometimes this infrastructure is available publicly. When it is, agreements can usually be worked out for payment via the GSA credit card or another established method. If refueling stations are not available in your area, you might consider installing either a private station on your site or a public station in partnership with other local fleets.

\section{Federal Sector Potential}

\section{Estimated Savings and Market Potential}

The operating costs of alternative fuel vehicles vary by region and by vehicle and fuel type. Therefore, fairly large 
fleets are the most likely ones to realize substantial cost savings using AFVs. This is especially true if an on-site refueling infrastructure is required and if the costs of that infrastructure must be recouped before calculating cost savings. The Appendix contains examples of cost analyses for a fleet using both natural gas and ethanol as alternative fuels. In general, these calculations vary according to the size and location of the fleet, the fuel selected, and the level of fuel use.

It is difficult to calculate the effect that AFVs could have on direct dollar savings for the Federal fleet as a whole, because many variables influence a cost-per-mile calculation. Vehicle cost, fuel cost, fuel availability, and maintenance are all important factors to consider in the overall cost picture.

\section{Laboratory Perspective}

As a part of its AFV market development efforts, the U.S. Department of Energy (DOE), through the DOE National Renewable Energy Laboratory (NREL), conducted a series of vehicle evaluations that compared commercially available alternative fuel vehicles with similar, conventionally fueled vehicles. To date, the program has tested dedicated CNG vehicles (the Honda Civic sedan, the Dodge full-size van, and the Ford F-series pickup), bi-fuel natural gas vehicles (the GMC Sierra pickup), bi-fuel propane vehicles (the Ford F-series pickup), and ethanol flexiblefuel vehicles (the Ford Taurus sedan and the Dodge Caravan minivan). Table 1 summarizes the emissions results. Some general comments about the test results follow.

Dedicated Natural Gas Vehicles. The natural gas Honda Civic achieved 8\% higher fuel efficiency (city and highway combined) than the comparable gasoline-fueled Civic. The natural gas van and pickup achieved about the same combined city/highway

\begin{tabular}{|c|c|c|c|c|c|c|c|c|}
\hline \multirow[t]{2}{*}{ Vehicle Type } & \multicolumn{4}{|c|}{ Alternative Fuel (g/mi) } & \multicolumn{4}{|c|}{ Gasoline (g/mi) } \\
\hline & NMHC & $\mathrm{CO}$ & $\mathrm{NO}_{\mathrm{x}}$ & $\mathrm{CO}_{2}$ & NMHC & $\mathrm{CO}$ & $\mathrm{NO}_{\mathrm{x}}$ & $\mathrm{CO}_{2}$ \\
\hline $\begin{array}{l}1998 \text { Ford Taurus } \\
\text { FFV Ethanol }\end{array}$ & 0.100 & 1.48 & 0.12 & 396.40 & 0.100 & 1.13 & 0.090 & 439.70 \\
\hline $\begin{array}{l}1998 \text { Ford F250 } \\
\text { Dedicated CNG }\end{array}$ & 0.000 & 0.48 & 0.06 & 548.70 & 0.140 & 1.29 & 0.310 & 660.75 \\
\hline $\begin{array}{l}1998 \text { GMC Sierra } \\
\text { Bi-Fuel CNG }\end{array}$ & 0.070 & 3.90 & 0.43 & 593.40 & 0.210 & 2.32 & 0.650 & 744.90 \\
\hline $\begin{array}{l}1998 \text { Honda Civic } \\
\text { Dedicated CNG }\end{array}$ & 0.003 & 0.16 & 0.02 & 219.25 & 0.079 & 1.60 & 0.065 & 295.70 \\
\hline $\begin{array}{l}1998 \text { Dodge Caravan } \\
\text { FFV Ethanol }\end{array}$ & 0.160 & 2.13 & 0.40 & 469.80 & 0.130 & 0.88 & 0.310 & 512.50 \\
\hline $\begin{array}{l}1999 \text { Dodge B2500 } \\
\text { Dedicated CNG }\end{array}$ & 0.010 & 0.66 & 0.30 & 721.10 & $\mathrm{~N} / \mathrm{A}$ & $\mathrm{N} / \mathrm{A}$ & $\mathrm{N} / \mathrm{A}$ & N/A \\
\hline $\begin{array}{l}1999 \text { Ford F250 } \\
\text { Bi-Fuel Propane }\end{array}$ & 0.040 & 1.04 & 0.26 & 658.40 & 0.090 & 0.53 & 0.100 & 723.70 \\
\hline $\mathrm{N} / \mathrm{A}=$ not tested & & & & & & & & \\
\hline
\end{tabular}

\begin{tabular}{|c|c|c|c|c|c|c|}
\hline \multirow[t]{2}{*}{ Vehicle Type } & \multicolumn{3}{|c|}{ AFV Fuel Economy (mpg) } & \multicolumn{3}{|c|}{ Gasoline Fuel Economy (mpg) } \\
\hline & City & Highway & Combined & City & Highway & Combined \\
\hline $\begin{array}{l}1998 \text { Ford Taurus } \\
\text { FFV Ethanol }\end{array}$ & 12.8 & 20.3 & 16.4 & 17.6 & 28.0 & 22.5 \\
\hline $\begin{array}{l}1998 \text { Ford F250 } \\
\text { Dedicated CNG }\end{array}$ & 11.6 & 15.3 & 14.6 & 12.6 & 15.5 & 14.5 \\
\hline $\begin{array}{l}1998 \text { GMC Sierra } \\
\text { Bi-Fuel CNG }\end{array}$ & 10.9 & 15.1 & 13.4 & 11.4 & 15.5 & 14.1 \\
\hline $\begin{array}{l}1998 \text { Honda Civic } \\
\text { Dedicated CNG }\end{array}$ & 24.3 & 34.2 & 31.1 & 23.5 & 32.0 & 28.5 \\
\hline $\begin{array}{l}1998 \text { Dodge Caravan } \\
\text { FFV Ethanol }\end{array}$ & 11.5 & 15.9 & 13.8 & 15.7 & 22.1 & 18.7 \\
\hline $\begin{array}{l}1999 \text { Dodge B2500 } \\
\text { Dedicated CNG }\end{array}$ & 10.6 & 14.2 & 13.0 & $\mathrm{~N} / \mathrm{A}$ & $\mathrm{N} / \mathrm{A}$ & $\mathrm{N} / \mathrm{A}$ \\
\hline $\begin{array}{l}1999 \text { Ford F250 } \\
\text { Bi-Fuel Propane }\end{array}$ & 8.4 & 11.8 & 10.7 & 11.4 & 16.3 & 14.9 \\
\hline $\mathrm{N} / \mathrm{A}=$ not tested & & & & & & \\
\hline
\end{tabular}

fuel efficiency as their gasoline-fueled counterparts (see Table 2).

In terms of emissions performance, results for pollutants were significantly lower for the natural gas vehicles than for comparable gasoline vehicles. The natural gas vehicles averaged about
$96 \%$ lower for nonmethane hydrocarbons, between $60 \%$ and $90 \%$ lower for carbon monoxide, and between $70 \%$ and $80 \%$ lower for oxides of nitrogen. The natural gas vehicles also emitted between $17 \%$ and $26 \%$ less carbon dioxide (a GHG) than comparable gasoline-fueled vehicles did. 


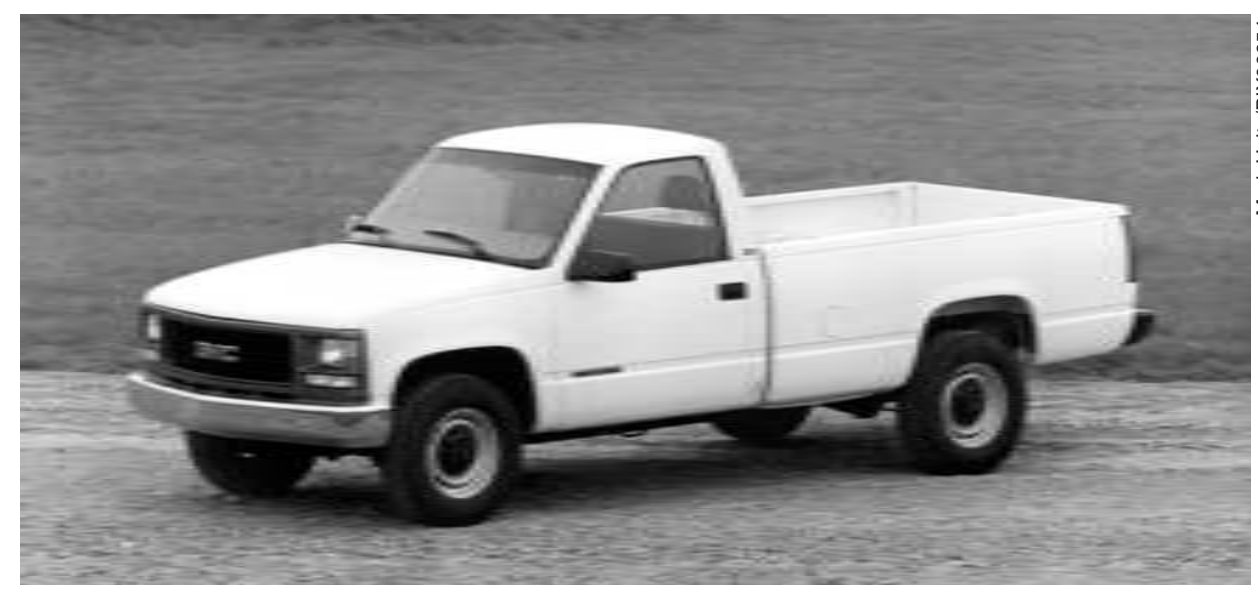

In 1998, this GMC bi-fuel C2500 pickup was part of a group of AFVs tested at the Transportation Research Center in Ohio.

Bi-Fuel Natural Gas Vehicles. The bi-fuel Sierra achieved $4 \%$ lower fuel efficiency (city and highway combined) operating on natural gas than the comparable gasoline-fueled model. This bifuel vehicle tested about $67 \%$ lower for nonmethane hydrocarbon emissions when operating on natural gas, however. It was rated about 33\% lower for oxides of nitrogen. And it emitted about $20 \%$ less carbon dioxide than comparable gasoline-fueled vehicles did. However, the bi-fuel Sierra operating on natural gas tested about $70 \%$ higher than the comparable gasoline vehicle for carbon monoxide, indicating that the vehicle was not fully optimized for operation on natural gas.

Bi-Fuel Propane Vehicles. The propane pickup truck achieved $28 \%$ lower fuel efficiency (city and highway combined) on a per-gallon basis than the comparable gasoline-fueled model. This occurred because a gallon of propane has about $70 \%$ of the energy of a gallon of gasoline. However, on an energy equivalent basis (i.e., miles traveled per Btu of fuel used), the propane and gasoline vehicles had nearly the same fuel efficiency. The propane vehicle tested about $55 \%$ lower for nonmethane hydrocarbon emissions. For oxides of nitrogen, the propane vehicle scored about $60 \%$ higher, however. It emitted about 9\% less carbon dioxide than comparable gasoline-fueled vehicles did, overall. But the propane pickup truck tested about $50 \%$ higher for carbon monoxide than the comparable gasoline vehicle did, indicating that the vehicle was not fully optimized for operation on propane.

Flexible-Fuel Ethanol Vehicles. The ethanol vehicles achieved between $25 \%$ and 30\% lower fuel efficiency (city and highway combined) on a per-gallon basis than the comparable gasolinefueled model did. This is because a gallon of ethanol (as E85) has about $70 \%$ of the energy of a gallon of gasoline. On an energy equivalent basis, however, the ethanol vehicles had nearly the same (or slightly higher) fuel efficiency as the gasoline vehicles.

The Dodge minivan's emissions performance on E85 was worse than that of the comparable gasoline vehicle for all three pollutants tested. The ethanol vehicle tested about 19\% higher for nonmethane hydrocarbon emissions, about $60 \%$ higher for carbon monoxide, and about $23 \%$ higher for oxides of nitrogen.

The Taurus sedan's performance on ethanol showed slightly different trends. The ethanol vehicle showed no difference relative to the gasoline vehicle for nonmethane hydrocarbons; it scored about 23\% higher for carbon monoxide and about $33 \%$ lower for oxides of nitrogen. These emissions results indicate that the vehicle was not fully optimized for operation on E85. Both ethanol vehicles emitted about $9 \%$ less carbon dioxide than comparable gasoline-fueled vehicles did, however.

For more information about the technical performance of AFVs, see the DOE Web site on advanced vehicle testing (www.ott.doe.gov/otu/field_ops/).

\section{Application}

This section addresses technical aspects of using alternative fuels in your agency's fleets, including the types of activities and conditions that are most suited to the use of AFVs. Advantages, limitations, and benefits of each fuel type are described. Also discussed are fuel selection and the installation and use of a refueling infrastructure.

\section{Application Screening}

Determining the most suitable vehicle and fuel for your facility is an important first step in purchasing alternative fuel vehicles.

Vehicle Selection. The ideal candidates for AFVs are vehicles that are operated primarily on or near your site. Because alternative fuels are commercially available only in limited quantities and locations, it can be difficult for drivers to locate suitable refueling stations. So, for applications in which vehicles must be driven some distance from the site or the fuel source, dualfuel vehicles are more suitable.

The ranges of most AFVs on the market today (except for electric vehicles) are comparable to the ranges of traditionally fueled vehicles. And AFVs come in a wide variety of configurations in light-duty and heavy-duty models.

Historically, most AFVs have been conversions. In these vehicles, engines and fuel storage tanks have been modified to accommodate alternative fuels. 


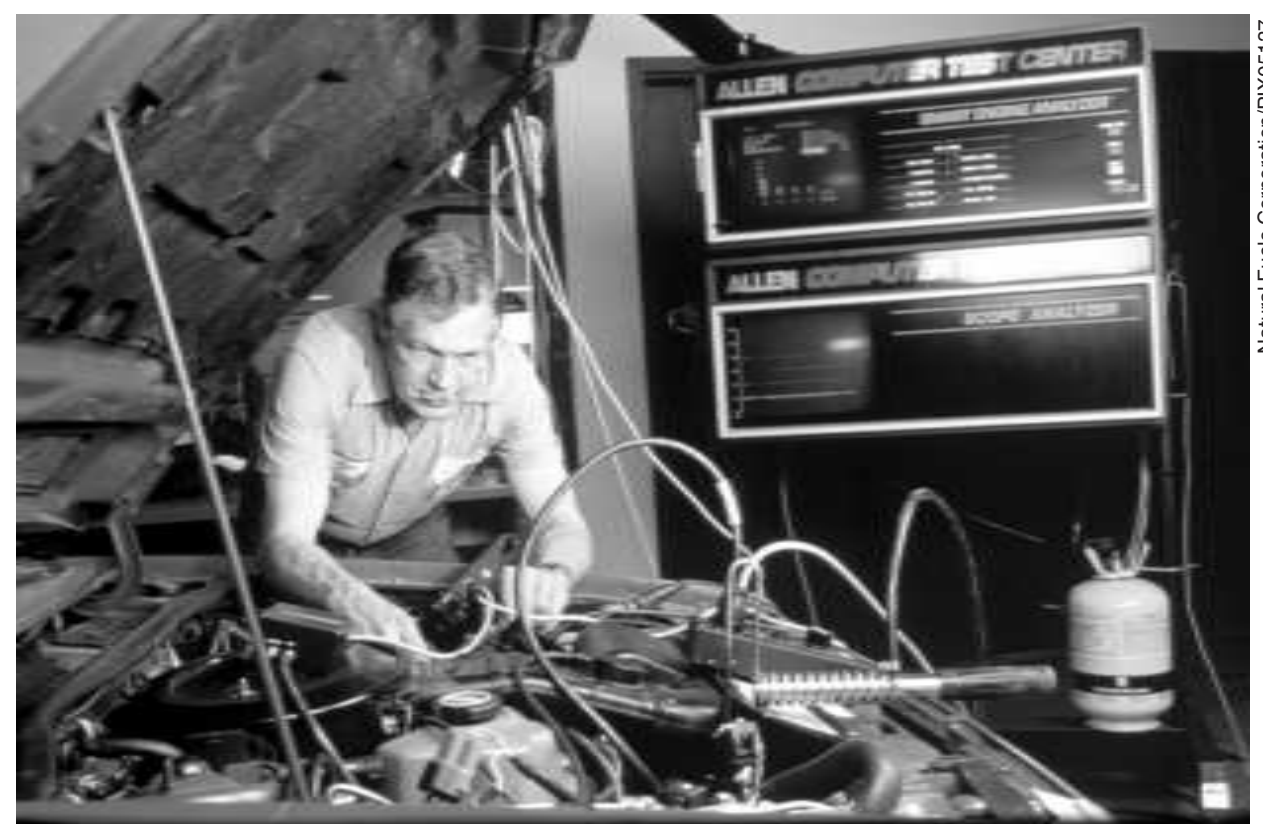

A technician performs a quality inspection of an aftermarket-conversion AFV that runs on ethanol.

However, the marketplace has changed dramatically, and today most vehicle manufacturers offer factory-produced models. GSA renegotiates the prices and availability of AFVs with manufacturers every year, just as the agency does for gasoline and diesel fuel vehicles.

Fuel Selection. In addition to selecting specific alternative fuel fleet vehicles, you also need to select the fuel type most suited to your fleet's mission and operations. This depends on several factors, including the cost and availability of a particular fuel in your area.

\section{Where to Apply}

The best places to implement AFVs are in large fleets that can refuel right on a Federal facility's site or at a nearby public refueling station. Operators of large fleets that can use alternative fuels and refuel on their own sites are often able to negotiate good prices with fuel suppliers. Where these conditions do not apply, another option is to partner with local fleet owners in building a suitable new alternative refueling station.

Large fleets can virtually guarantee a significant volume of business to a private company that will consider adding alternative fuels to its stations or opening a new public station providing these fuels. Several fleet operators who use public stations have actually convinced local suppliers to build a new station, at no cost to the fleet, by making a commitment to providing a large volume of business at that station for a certain period of time.

\section{What to Avoid}

Here are some key things to avoid when using AFVs in Federal fleets:

- Purchasing dedicated AFVs when the fuel supply is questionable. Be sure that you can access fuel easily for dedicated AFVs, or consider purchasing bi-fuel vehicles.

- Not properly training and educating fleet operators about the differences among $A F V s$. For example, different methods are used to fill up a vehicle with CNG than with liquid fuel.

- Not having a conveniently located public refueling station, or locating an on-site refueling station in an out-of-the-way spot. Most drivers will not want to go out of their way to refuel. For convenience, it's also a good idea to try to coordinate refueling with other routine activities of your fleet.

- Not showing full support for AFVs. Drivers tend to embrace a new technology when they are assured that their agency has made a commitment to it and that it is not simply the "flavor of the month."

\section{Equipment Integration}

Ideally, refueling stations for AFVs should be as convenient as traditional refueling stations. Locate on-site alternative refueling stations on or near your on-site gasoline and diesel stations, whenever possible. This makes it easier for drivers to refuel different kinds of vehicles.

If you use a public alternative refueling station, it is preferable to choose one that is close to the gasoline or diesel stations that your fleet already uses, and not more than a five-minute drive from your fleet's headquarters. These public stations should also accept your fleet's credit card or other preferred method of payment.

\section{Maintenance Impact}

Vehicle maintenance intervals for AFVs are similar to those required for conventionally fueled vehicles. Because some of the equipment installed on AFVs is unique, special training or tools may be required for certain maintenance procedures, such as pressure-testing CNG systems for leaks. Automobile dealerships authorized to sell AFVs are usually trained in maintenance and repair. At present, however, only a limited number of dealerships are trained and equipped to perform maintenance on natural gas, electric, and propane AFVs.

\section{Equipment Warranties}

Alternative fuel vehicles purchased from major vehicle manufacturers carry a manufacturer's warranty. When AFVs are leased from GSA, 


\section{FE DERAL ENERG}

MANAGE MENT
$P R O G R A M$ fuel costs and maintenance are included in the cost of the lease, as they are for traditionally fueled GSA leased vehicles. Warranties for infrastructure vary and depend on the type of contract developed with the individual infrastructure developer or supplier.

\section{Codes and Standards}

There are no restrictions on the operation of AFVs sold by vehicle manufacturers. All vehicles sold by manufacturers are certified by the Federal government to be acceptable on public roads and to comply with current regulations for safety and emissions. Codes and standards applicable to the refueling infrastructure vary from state to state, however, and even from one locality to another. Your refueling station contractor and other fleets in your area may be able to provide more information.

Alternative fuel trade associations can be another good source of information about local codes and standards. Several of these associations are listed in the back of this publication.

\section{Costs}

Alternative fuel vehicles usually cost more than similar gasoline or diesel fuel vehicles. Averaged incremental costs for AFVs are shown in Table 3. These are based on GSA prices from the 2001 model year.

\section{Table 3. Incremental Costs for Selected Alternative Fuel Vehicles (averages)}

\begin{tabular}{ll} 
Vehicle Type & for Incremental Cost \\
Ethanol Sedan & $\$ 70$ \\
CNG Sedan & $\$ 5,400-7,800$ \\
$\begin{array}{l}\text { Ethanol Pickup Truck } \\
\text { (Compact) }\end{array}$ & $\$ 250$ \\
$\begin{array}{l}\text { LPG Pickup Truck } \\
\text { (Full-Size) }\end{array}$ & $\$ 2,300-6,400$ \\
CNG Van & $\$ 3,500-5,100$ \\
$\begin{array}{l}\text { CNG Pickup Truck } \\
\text { (Full-Size) }\end{array}$ & $\$ 1,700-7,100$ \\
\hline
\end{tabular}

Prices for alternative fuels can fluctuate greatly, depending on markets, weather patterns, and traditional fuel (i.e., oil) prices. Therefore, it is difficult to predict the exact prices of alternative fuels on a per-gallon basis or to determine whether or not these prices will be higher or lower than gasoline prices.

Largely because alternative fuel prices are not yet predictable, it is difficult to estimate near-term cost savings associated with their use, and it is unlikely that these savings will be significant. Because of this uncertainty, and because E.O. 13149 requires Federal fleets to use these technologies regardless of cost, GSA has developed an innovative pricing and billing method known as the surcharge program. This voluntary program is available to Federal agencies and spreads out the incremental costs of AFVs over time.

Under the program, GSA adds a surcharge to the cost of every vehicle that an agency leases; the surcharge is established and authorized by the participating agency. Money from the surcharges is automatically used to defray the incremental lease costs of the fleet's AFVs, and fleets thus pay the same lease rate for AFVs as they do for conventional vehicles. Program participants include agencies such as DOE and the Department of the Army.

Several other special programs also provide incentives for purchasing AFVs in various metropolitan areas and regions of the country. For more information, see www.fleets.doe.gov/.

\section{Utility Incentives and Support}

Especially for large fleets, natural gas is usually either competitive or favorable in price in comparison to gasoline or diesel fuel. This is so because, in most cases, the price is based on the total amount of gas a facility uses, including the amount used to heat buildings, water, and so on. So, because of the increase in the total gas order, the agency is in a good position to negotiate with a supplier for a competitive price.
Other alternative fuels, which are usually purchased in smaller amounts, are generally more expensive than gasoline. Because unit prices drop in largevolume purchases, however, agencies might want to work with other local fleets to place one large, combined order for the alternative fuel.

If your agency is using a public refueling station to obtain an alternative fuel, try to negotiate the price up front, if possible. If your fleet can commit to a certain amount of business based on the number of AFVs that will use the public station, you might be able to negotiate a set price or a "not-toexceed" price with that station.

\section{Hypothetical Case Study: GSA-Leased Fleet, Rural Texas}

This case study is hypothetical, but it represents a fairly typical situation for many Federal facilities that operate medium-sized or large fleets. See the Appendix for a more detailed cost analysis associated with this study.

\section{Facility Description}

A large fleet in rural Texas owns 1000 vehicles and replaces an average of 150 vehicles per year. All of the vehicles are leased from GSA. The fleet operates a majority of the vehicles (about $80 \%$ ) on its own property. Vehicles that travel off the property are generally sedans or vans used to transport passengers rather than equipment. The fleet has its own garage, and most maintenance and repairs are done on site.

\section{Existing Technology Description}

Primarily, the fleet operates gasoline vehicles. A few bi-fuel pickup trucks that can operate on gasoline or CNG have been purchased in the last two years as part of a pilot $C N G$ vehicle program. The fleet has been refueling the CNG vehicles using a slow-fill refueling capability—also called a "station"—on the site. 


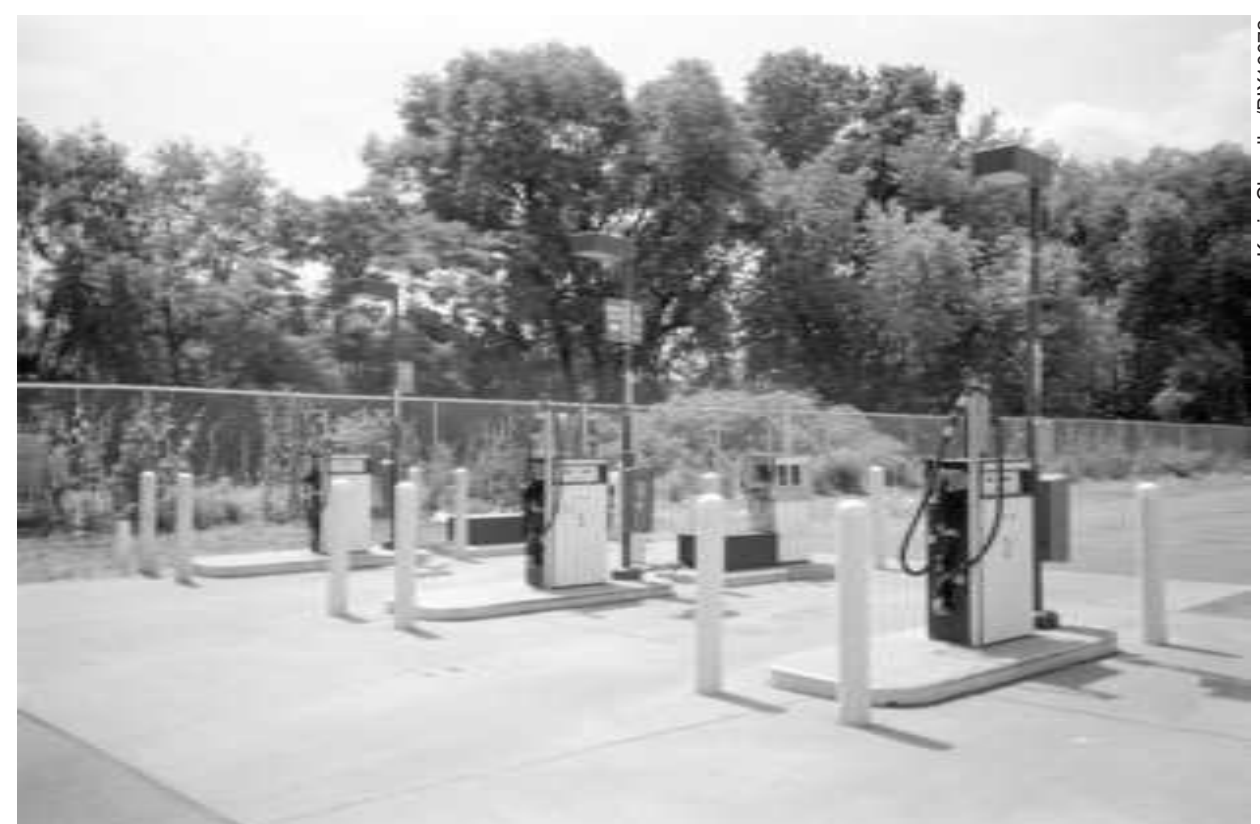

United Parcel Service is one of many organizations that maintain their own compressor stations and fueling islands; these are for a fleet of UPS CNG trucks in Connecticut.

\section{New Technology Equipment Selection}

The fleet operators have decided that more trucks and large vans using CNG would be appropriate for this fleet. Because most of the vehicles are refueled on site, a fast-fill refueling station will be installed to support the additional CNG vehicles. The fleet operators have also decided to use dedicated CNG vehicles rather than bi-fuel CNG vehicles, because the onsite CNG fast-fill station will make it easy to access fuel for these vehicles regularly. In addition, purchasing medium-duty and heavy-duty dedicated $\mathrm{CNG}$ vehicles will earn the agency extra credits toward compliance with E.O. 13149.

The fleet operators have also decided to begin obtaining flexible-fuel sedans and minivans that can run on gasoline or ethanol. Although the fleet does not currently have a refueling capability on site for ethanol, it can use gasoline until there are enough vehicles to justify converting one of the gasoline pumps to ethanol. This will give the fleet EPAct compliance credits for acquiring alternative fuels right away, as well as the option of using ethanol to reduce petroleum usage in the future. In addition, since the sedans and minivans are usually driven off site for long distances, the flexiblefuel configuration allows fleet drivers to refuel with gasoline, if necessary, when they are far from an ethanol refueling station.

\section{Savings Potential}

Installing a CNG fast-fill refueling station will be a significant undertaking for this fleet. Slow-fill stations cost only about $\$ 5,000$ dollars per appliance, but a large-volume, fast-fill station can cost from $\$ 300,000$ to $\$ 1$ million or more, depending on the specific location and other factors. In addition, the incremental cost of the new CNG vehicles will range from $\$ 1,700$ to $\$ 7,100$ per vehicle. Nevertheless, the Texas fleet's operators have decided to go ahead with this decision, for several reasons.

First, these actions seem to be the best way for the fleet to comply with E.O. 13149. Whenever possible, the fleet operators will purchase dedicated CNG trucks and vans. These vehicles, which weigh more than $8,500 \mathrm{lb}$., earn additional compliance credits and use the most fuel-they are less fuel efficient than some other types. By converting these large, inefficient vehicles to alternative fuel, the fleet also achieves a greater reduction in the use of imported petroleum. Second, the fleet's drivers are already accustomed to using CNG vehicles because of the pilot program, and the garage has been learning proper maintenance techniques. Finally, because of the regular increase in the amount of CNG the fleet will need to purchase, the facility can negotiate a better rate from the gas company and thus reduce the facility's heating costs, as well.

In contrast to the relative complexity of the decision to use CNG vehicles, it was not difficult for operators to decide to begin acquiring flexible-fuel (ethanol and gasoline) vehicles for this fleet. These vehicles have virtually no incremental costs, and they can operate on traditional fuels when the alternative fuel is not available. Because the facility's vehicles are refueled primarily on site, the facility can rather easily convert one gasoline refueling pump to ethanol when there are enough vehicles to support the switch. The switchover will be inexpensive, because only a new tank and a few new lines will be required. The pump and meters can be the same as those formerly used to dispense gasoline.

\section{Implementation and Post-Implemen- tation Experience}

Initially, it will be a challenge to maintain both the new AFVs and the refueling site. The tools and procedures needed for CNG vehicles are different from those associated with the traditional vehicles and infrastructure. So, appropriate training is needed for maintenance crews. Once the crews are fully trained, however, they will be able to operate and maintain the AFVs and the new refueling station easily. 


\section{The Technology in Perspective The Technology's Development}

Alternative fuel vehicles have been around a long time. The earliest selfpropelled roadway vehicles were steam-powered and appeared in the 18 th century. At the turn of the 20th century, most of the vehicles sold in the United States were electric cars. Even as late as 1920, members of the Ford Motor Company family preferred to use their electric vehicles, because electrics were quieter and cleaner in terms of emissions.

But electric vehicles were rapidly giving way in popularity to those with a gasoline-powered combustion engine, and Henry Ford sold thousands of his moderately priced Model T automobiles in the early part of the 20th century. Today's renewed interest in alternative vehicles probably began during the gasoline shortages of the 1970s and increased during the Gulf War of the 1990s, largely because of supply and cost issues associated with imported oil.

Beginning in the 1993 model year, vehicle manufacturers who are required to meet certain fuel efficiency standards were able to receive credits for producing AFVs. These credits indicate that AFVs are considered to be more fuel efficient than comparable gasoline or diesel fuel vehicles. At about the same time, several regulations also required fleets to minimize air pollution and purchase AFVs. Fleet owners who were required by regulations to purchase AFVs began creating additional demand, and there were new incentives for manufacturers to sell these vehicles to earn fuel economy credits.

Initially, the primary focus was on natural gas and propane vehicles, which have always been fairly common in the heavy-duty $(8,500-14,000 \mathrm{lb}$.) class of vehicles. Then, some manufacturers began producing methanol vehicles in a flexible-fuel configuration, which has evolved into the use of ethanol in flexible-fuel vehicles. Today, a wide variety of fuel and vehicle options are available in many vehicle classes.

\section{Technology Outlook}

It is somewhat difficult to predict the future of AFVs and alternative motor fuels. There are enough vehicles on the road today, particularly in fleets, to make the support system and infrastructure fairly stable. However, it is not easy to predict the market growth of these products. In order for alternative fuels to be used widely, AFVs need to reach the general driving public in significant numbers.

Increasing the market for AFVs could be somewhat difficult, as well. On the one hand, consumers might hesitate to purchase AFVs until commercial refueling stations for alternative fuels are readily available. On the other hand, private fuel station owners might hesitate to increase the alternative refueling infrastructure by adding new stations until there are enough vehicles to make the stations economically viable. Therefore, the current focus is on fleets that can either operate their own stations or work with local fuel suppliers to commit to a certain amount of business at an established station. Fleets that operate stations themselves are also encouraged to open them up to the public, so more U.S. drivers will have access to alternative fuels.

To help mitigate the obstacles to more widespread use, the Federal government continues to provide incentives to fleets to acquire AFVs. And legislation is proposed frequently to stimulate the AFV market. Concerns about global warming and unstable gasoline prices could also spur increases in our nation's use of alternative fuels and AFVs.

\section{Federal Program Contacts}

For more information on alternative fuel vehicle programs for Federal fleets, contact Shabnam Fardanesh, DOE, 202-586-7011, or Kathleen Nawaz, NREL, 202-646-5059.

\section{Who is Using the Technology}

\section{Federal Sites}

Many Federal fleets use AFVs and alternative fuels, primarily to meet the requirements of EPAct and E.O. 13149. All around the country, agencies such DOE, the U.S. Postal Service, the Marine Corps, and the Navy have done an excellent job of acquiring AFVs and locating or installing an alternative refueling infrastructure near their facilities. For more information, contact Shabnam Fardanesh, DOE, 202-586-7011, or Kathleen Nawaz, NREL, 202-646-5059.

\section{Non-Federal Sites}

Many organizations, such as SuperShuttle and Schwan's Sales Enterprises, use alternative fuel vehicles. In addition, many state agencies also have fleets of AFVs. For more information about non-Federal fleets that operate AFVs, contact the DOE Regional Office or Duty Station liaison for your state (see the list below). Because DOE works closely with local fleets and Clean Cities coalitions to advance alternative fuels, the DOE contacts listed in this publication can provide more information about local and regional activities.

Atlanta Region (AL, AR, FL, GA, KY, MS, NC, SC, TN)

David Dunagan

404-562-0561

Boston Region (CT, MA, ME, NH, NY, RI, VT)

Michael Scarpino

617-565-9716

Chicago Region (IN, IL, IA, MI, MN, $\mathrm{MO}, \mathrm{OH}, \mathrm{WI}$ ) 
Melinda Latimer

312-886-8582

Dallas Duty Station (LA, NM, OK, TX)

Dan Deaton

972-491-7276

Denver Region (CO, KS, MT, ND, NE, SD, UT, WY)

Ernie Oakes

303-275-4817

Philadelphia Region (DC, DE, MD, NJ, PA, VA, WV) James Ferguson

215-656-6977

Oakland Duty Station (CA)

Julia Oliver

510-637-1952

Seattle Region (AK, AZ, HI, ID, NV,

OR, WA)

Roxanne Dempsey

206-553-2155

\section{For More Information}

\section{Alternative Fuel Associations}

Natural Gas Vehicle Coalition

1100 Wilson Blvd., Suite 850,

Arlington, VA 22209

703-527-3022

www.ngvc.org

National Biodiesel Board

3337A Emerald Lane

Jefferson City, MO 65110

800-841-5849

biodiesel@sockets.net

www.biodiesel.org

National Ethanol Vehicle Coalition

Phillip Lampert

3118 Emerald Lane

Jefferson City, MO 65109

877-485-8595

nevc@e85fuel.com

www.E85fuel.com

Electric Vehicle Association of the

Americas

701 Pennsylvania Avenue, NW

Fourth Floor

Washington, DC 20004

202-508-5995

www.evaa.org
Propane Vehicle Council

1130 Connecticut Ave. N.W., Suite 700

Washington, DC 20036

202-530-0479

vehicle@propanegas.com

\section{Other References}

Alternative Fuel Data Center

800-423-1363

www.afdc.doe.gov

DOE's Federal Fleet Program

www.fleets.doe.gov/

DOE's Field Operations Testing Program

www.ott.doe.gov/otu/field_ops 
FEDERAL ENERGY MANAGEMENT PROGRAM

Appendix: AFV Life-Cycle Cost Analysis 


\section{AFV Life-Cycle Cost Analysis}

\section{Cost Analysis 1: Ethanol (E85)}

A fleet currently operates approximately 1000 vehicles. It purchases an average of 150 replacements per year. Each vehicle drives 15,000 miles per year, and the average fuel economy for the fleet is 20 miles per gallon. The fleet manager chooses to convert approximately half of the fleet to ethanol (E85). This means that of the 150 vehicles purchased each year, 75 of them will be E85 vehicles, and it will take approximately 6 years to fully convert. Because the fleet usually replaces vehicles when they are 7 years old, the fleet will continue to purchase approximately 75 vehicles each year; when the fleet is fully converted after 6 years, the first E85 vehicles purchased will be replaced.

The fleet has a contract for gasoline at $\$ 1.60$ per gallon and a contract for E85 at $\$ 1.65$ per gallon. Refueling for the fleet is currently conducted using on-site gasoline pumps. In order to support the new ethanol vehicles, current gasoline pumps will be converted to ethanol at a cost of approximately $\$ 50,000$. Because the fleet is located near other fleets in the area, they have agreed to allow others to use their E85 facility to refuel at a rate of $\$ 1.75$ per gallon for approximately 78,000 gallons per year, or 6,500 gallons per month. Maintenance and replacement costs for the E85 pumps are comparable to those for the gasoline pumps.

\section{Cost Analysis 2: Compressed Natural Gas (CNG)}

A fleet currently operating approximately 1000 vehicles purchases, on average, 150 replacements per year. Each vehicle drives 10,000 miles per year and the average fuel economy for the fleet is 20 miles per gallon. The fleet manager decides to convert approximately half of the fleet to CNG. This means that of the 150 vehicles purchased each year, 75 of them will be CNG vehicles, and it will take approximately 6 years to fully convert. Because the fleet generally replaces vehicles when they are 7 years old, the fleet will continue to purchase approximately 75 vehicles each year; when the fleet is fully converted after 6 years, the first CNG vehicles purchased will be replaced.

The fleet has a contract for gasoline at $\$ 1.60$ per gallon and a contract for $\mathrm{CNG}$ for $\$ 0.80$ per gallon. The refueling facility for the fleet is currently composed of on-site gasoline pumps. In order to support the new CNG vehicles, a CNG facility will be installed on site at a cost of $\$ 500,000$. Because the fleet is located near other fleets in the area, this fleet has agreed to allow the others to use the CNG facility to refuel at a rate of $\$ 0.95$ per gallon for approximately 78,000 gallons per year, or 6,500 gallons per month. Maintenance and replacement costs for the CNG station are comparable to that for the gaso-line pumps.

\section{Assumptions:}

- A 10-year study period was assumed.

- Seventy-five vehicles must be purchased.

- The base case (traditional gasoline) vehicle has a purchase price of $\$ 16,000$.

- The ethanol (E85) vehicle was assumed to cost \$16,070 (a \$70 cost differential) and the CNG vehicle was assumed to cost $\$ 23,000$ (a $\$ 7,000$ cost differential).

- Each vehicle is driven an average of 12,000 miles per year.

- The traditional gasoline-fueled vehicle gets $20 \mathrm{mpg}$ and the AFVs get $18 \mathrm{mpg}$.

- Fueling station costs were assumed as follows:

- Ethanol fueling station: $\$ 50,000$

- CNG fueling station: $\$ 500,000$

- The following fuel costs were assumed:

- Gasoline: U.S. average price of \$1.545/gallon

- Ethanol: \$2.00/gallon; based on EIA report referencing the "cost of ... \$1.10 per gallon for ethanol produced from corn and [compared with] today's wholesale price for gasoline of between $\$ 0.80$ and $\$ 0.90$ per gallon." This ratio of price difference is 1.29 (i.e., ethanol costs about $29 \%$ more to produce than gasoline). Assuming this additional production cost will be passed on to the consumer in the same proportion, $1.29 \times \$ 1.545=\$ 2.00 /$ gallon.

- CNG: \$1.12/gallon; based on two different estimates (one from PNGV and one from the University of Buffalo) stating that "for the same energy content CNG costs about 35 percent less than gasoline." The University of Buffalo study indicates "CNG costs approximately 20 percent less than gasoline." Taking an average of these two numbers, and using the current national average price of gasoline of $\$ 1.545 /$ gallon, the cost of CNG is approximately $\$ 1.12 /$ gallon. 


\section{Results:}

\begin{tabular}{lccr} 
& Gasoline (Base Case) & Ethanol (E85) & \multicolumn{1}{c}{ CNG } \\
Cost of 75 vehicles & $\$ 1,200,000$ & $\$ 1,205,250$ & $\$ 1,725,000$ \\
Annual fuel consumption & 69,525 & 100,000 & 56,000 \\
Cost of refueling station & 0 & 50,000 & 500,000 \\
PV of fuel costs & 551,000 & 792,000 & 386,000 \\
LCC & $\$ 1,751,000$ & $\$ 2,042,000$ & $\$ 2,416,000$ \\
Net savings & - & $-\$ 289,000$ & $-\$ 663,000$
\end{tabular}

Notes:

This analysis assumed that CNG costs will escalate at the same rate as natural gas costs for an industrial customer, and that ethanol costs will escalate at the same rate as gasoline. DOE escalation rates have indicated that gasoline costs will decrease in the next 10 years rather than increase.

PV is present value; UPV is uniform present value; LCC is life-cycle cost.

$\mathrm{PV}$ of fuel costs $=$ net present value of fleet vehicle fuel costs for the 10-year study period.

PV of fuel costs $=$ (current year cost of fuel) $\times$ (FEMP UPV discount factor).

UPV discount factor for industrial natural gas, $\mathrm{n}=10$ years, United States average $=6.89$, used in the analysis for the CNG scenario.

UPV discount factor for transportation gasoline, $\mathrm{n}=10$ years, United States average $=7.92$, used in the base case and E85 scenarios.

Sources:

EIA U.S. Retail Gasoline Prices: www.eia.doe.gov/oil_gas/petroleum/data_/publications/wrgp/mogas_home_page.html.

EIA Reports, April 26, 2000: www.eia.doe.gov/neic/press/press156.html.

Goldblaum, Ellen. "Cleaner air on campus." State University of New York at Buffalo Reporter, Vol. 28, No. 3, September 12, 1996.

U.S. Department of Commerce, Technology Administration. National Institute of Standards and Technology. Energy Price Indices and Discount Factors for Life-Cycle Cost Analysis-April 2001. NISTIR 85-3273-16. Online at www.eren.doe.gov/femp/ techassist/softwaretools/softwaretools.html\#factors. 
FE DERAL ENERG Y MANAGEMENT PROGRAM 


\section{About FEMP's New Technology Demonstrations}

The Energy Policy Act of 1992 and subsequent Executive Orders mandate that energy consumption in Federal buildings be reduced by 35\% from 1985 levels by the year 2010. To achieve this goal, the U.S. Department of Energy's Federal Energy Management Program (FEMP) sponsors a series of activities to reduce energy consumption at Federal installations nationwide. One of these activities, new technology demonstrations, is tasked to accelerate the introduction of energy-efficient and renewable technologies into the Federal sector and to improve the rate of technology transfer.

As part of this effort, FEMP sponsors the following series of publications that are designed to disseminate information on new and emerging technologies:

Technology Focuses-brief information on new, energy-efficient, environmentally friendly technologies of potential interest to the Federal sector.

Federal Technology Alerts-longer summary reports that provide details on energy-efficient, water-conserving, and renewable-energy technologies that have been selected for further study for possible implementation in the Federal sector. Additional information on Federal Technology Alerts (FTAs) is provided in the next column.
Technology Installation Reviews - concise reports describing a new technology and providing case study results, typically from another demonstration program or pilot project.

Other Publications - the program also issues other publications on energysaving technologies with potential use in the Federal sector.

\section{More on Federal Technology Alerts}

Federal Technology Alerts, our signature reports, provide summary information on candidate energy-saving technologies developed and manufactured in the United States. The technologies featured in the FTAs have already entered the market and have some experience but are not in general use in the Federal sector.

The goal of the FTAs is to improve the rate of technology transfer of new energy-saving technologies within the Federal sector and to provide the right people in the field with accurate, up-todate information on the new technologies so that they can make educated judgments on whether the technologies are suitable for their Federal sites.

The information in the FTAs typically includes a description of the candidate technology; the results of its screening tests; a description of its performance, applications, and field experience to date; a list of manufacturers; and important contact information. Attached appendixes provide supplemental information and example worksheets on the technology.

FEMP sponsors publication of the FTAs to facilitate information-sharing between manufacturers and government staff. While the technology featured promises significant Federal-sector savings, the FTAs do not constitute FEMP's endorsement of a particular product, as FEMP has not independently verified performance data provided by manufacturers. Nor do the FTAs attempt to chart market activity vis-a-vis the technology featured. Readers should note the publication date on the back cover, and consider the FTAs as an accurate picture of the technology and its performance at the time of publication. Product innovations and the entrance of new manufacturers or suppliers should be anticipated since the date of publication. FEMP encourages interested Federal energy and facility managers to contact the manufacturers and other Federal sites directly, and to use the worksheets in the FTAs to aid in their purchasing decisions.

\section{Federal Energy Management Program}

The Federal Government is the largest energy consumer in the nation. Annually, in its 500,000 buildings and 8,000 locations worldwide, it uses nearly two quadrillion Btu (quads) of energy, costing over $\$ 8$ billion. This represents $2.5 \%$ of all primary energy consumption in the United States. The Federal Energy Management Program was established in 1974 to provide direction, guidance, and assistance to Federal agencies in planning and implementing energy management programs that will improve the energy efficiency and fuel flexibility of the Federal infrastructure.

Over the years, several Federal laws and Executive Orders have shaped FEMP's mission. These include the Energy Policy and Conservation Act of 1975; the National Energy Conservation and Policy Act of 1978; the Federal Energy Management Improvement Act of 1988; the National Energy Policy Act of 1992; Executive Order 13123, signed in 1999; and most recently, Executive Order 13221, signed in 2001, and the Presidential Directive of May 3, 2001.

FEMP is currently involved in a wide range of energy-assessment activities, including conducting new technology demonstrations, to hasten the penetration of energy-efficient technologies into the Federal marketplace. 


\section{A Strong Energy Portfolio for a Strong America}

Energy efficiency and clean, renewable energy will mean a stronger economy, a cleaner environment, and greater energy independence for America. By investing in technology breakthroughs today, our nation can look forward to a more resilient economy and secure future.

Far-reaching technology changes will be essential to America's energy future. Working with a wide array of state, community, industry, and university partners, the U.S. Department of Energy's Office of Energy Efficiency and Renewable Energy invests in a portfolio of energy technologies that will:

- Conserve energy in the residential, commercial, industrial, government, and transportation sectors

- Increase and diversify energy supply, with a focus on renewable domestic sources

- Upgrade our national energy infrastructure

- Facilitate the emergence of hydrogen technologies as a vital new "energy carrier."

\section{The Opportunities}

Biomass Program

Using domestic, plant-derived resources to meet our fuel, power, and chemical needs

Building Technologies Program

Homes, schools, and businesses that use less energy, cost less to operate, and ultimately, generate as much power as they use

Distributed Energy \& Electric Reliability Program

A more reliable energy infrastructure and reduced need for new power plants
Federal Energy Management Program

Leading by example, saving energy and taxpayer dollars in federal facilities

FreedomCAR \& Vehicle Technologies Program

Less dependence on foreign oil, and eventual transition to an emissionsfree, petroleum-free vehicle

Geothermal Technologies Program

Tapping the earth's energy to meet our heat and power needs

Hydrogen, Fuel Cells \& Infrastructure Technologies Program

Paving the way toward a hydrogen economy and net-zero carbon energy future

Industrial Technologies Program

Boosting the productivity and competitiveness of U.S. industry through improvements in energy and environmental performance

Solar Energy Technology Program

Utilizing the sun's natural energy to generate electricity and provide water and space heating

\section{Weatherization \& Intergovernmental Program}

Accelerating the use of today's best energy-efficient and renewable technologies in homes, communities, and businesses

Wind \& Hydropower Technologies Program

Harnessing America's abundant natural resources for clean power generation

To learn more, visit www.eere.energy.gov
For More Information

FEMP Help Desk

800-363-3732

International callers please use

703-287-8391

Web site: www.eren.doe.gov/femp

\section{General Contacts}

Ted Collins

New Technology Demonstration

Manager

Federal Energy Management

Program

U.S. Department of Energy

1000 Independence Ave., S.W.,

EE-92

Washington, DC 20585

Phone: 202-586-8017

Fax: 202-586-3000

theodore.collins@ee.doe.gov

\section{Steven A. Parker}

Pacific Northwest National

Laboratory

P.O. Box 999, MSIN: K5-08

Richland, WA 99352

Phone: 509-375-6366

Fax: 509-375-3614

steven.parker@pnl.gov

Technical Contacts

Shabnam Fardanesh

Office of Transportation

Technologies

U.S. Department of Energy

1000 Independence Ave., S.W.,

EE-90

Washington, D.C. 20585

Phone: 202-586-7011

Fax: 202-586-1610

Kathleen Nawaz

National Renewable Energy

Laboratory

Washington Office

901 D Street, S.W., Suite 930

Washington, D.C. 20024-2157

Phone: 202-646-5059

Fax: 202-646-7780

kathleen_nawaz@nrel.gov

- Downloadable versions of publications in Adobe Portable Document Format (pdf)

- A list of new technology projects under way

- Electronic access to a regular mailing list for new products when they become available

- How Federal agencies may submit requests to us to assess new and emerging technologies

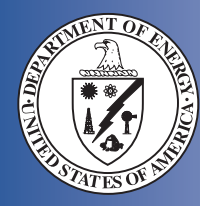

U.S. Department of Energy

Energy Efficiency and

Renewable Energy

Produced for the U.S. Department of Energy, Energy Efficiency and Renewable Energy, by the National Renewable Energy Laboratory, a DOE national laboratory

DOE/EE-0280

September 2003 